\title{
Kadar Interleukin 6 serum sebagai prediktor luaran rawat inap pada lanjut usia di Desa Pedawa Buleleng Bali
}

\author{
Wayan Giri Putra Semaradana ${ }^{1}$, I Gusti Putu Suka Aryana ${ }^{2}$, RA Tuty Kuswardhani ${ }^{2}$, I Nyoman Astika ${ }^{2}$, \\ Ida Bagus Putrawan², Ni Ketut Rai Purnami²
}

'Program Studi Penyakit Dalam, Fakultas Kedokteran Universitas Udayana/RSUP Sanglah, Denpasar, Bali, Indonesia

${ }^{2}$ Departemen/KSM Penyakit Dalam, Fakultas Kedokteran Universitas Udayana/RSUP Sanglah, Denpasar, Bali, Indonesia

Email:wayangiriputras@gmail.com
Tanggal diterima : 18 April 2018 Tanggal Disetujui : 11 Mei 2018 Tanggal Diterbitkan : 19 Mei 2018
Latar Belakang: Angka rawat inap semakin meningkat seiring pertambahan usia sehingga meningkatkan biaya kesehatan. Salah satu faktor risikonya adalah adanya immunosenescence. Inflamasi kronik merupakan penyebab dari immunosenescence dan dapat ditandai dengan peningkatan serum interleukin 6.

Tujuan: Mengetahui apakah kadar interleukin 6 (IL-6) serum merupakan prediktor terjadinya luaran rawat inap pada lanjut usia.

Metode: Penelitian ini merupakan studi prospektif analitik dengan jumlah sampel sebanyak 76 orang lanjut usia (usia $\geq 60$ tahun) di Desa Pedawa Buleleng Bali yang diambil secara stratified random sampling. Pemeriksaan IL-6 kadar serum memakai reagen Quantikine HS Human IL-6 Immonoassay dengan satuan $\mathrm{pg} / \mathrm{mL}$. Luaran rawat inap diobservasi selama 6 bulan. Analisis data berupa deskriptif, bivariat (uji komparasi dan uji tabulasi silang) dan analisis multivariat yang menggunakan regresi logistik.

Hasil: Rerata kadar IL-6 serum didapatkan 2,8 $\pm 4,09 \mathrm{pg} / \mathrm{mL}$. Dari hasil observasi selama 6 bulan, didapatkan subyek yang mengalami luaran rawat inap sebanyak 12 orang (15,8\%). Perbedaan rerata kadar IL-6 serum yang siginifikan didapatkan antara kelompok yang mengalami rawat inap (IK 95\%; $p<0,01)$ dibandingkan dengan yang tidak. Hasil regresi logistik menunjukkan bahwa kadar IL-6 serum tetap mempengaruhi terjadinya luaran rawat inap setelah mengendalikan variabel perancu (IK 95\%; $p<0,01)$. Uji chi-square menunjukkan subyek dengan kadar IL-6 serum tinggi mempunyai resiko relatif mengalami luaran rawat inap sebesar $18,8($ IK $95 \% ; p<0,01)$.

Simpulan: Kadar IL-6 serum yang tinggi merupakan prediktor luaran rawat inap lanjut usia.

Kata kunci: interleukin 6, rawat inap, lanjut usia

Background: The prevalens of hospitalizations increases with age thus increasing health costs. One of the risk factor is immunosenescence. Chronic inflammation was a cause of immunosenescence and can be characterized by an increase in serum interleukin 6.

Objective: This study aimed to determine whether serum interleukin 6 (IL-6) is a predictor for hospitalization in elderly. Methods: This was an analytical prospective study with total sample of 76 elderly people (aged $\geq 60$ years) in Pedawa village Buleleng Bali taken by stratified random sampling. Serum IL-6 was examined by Quantikine HS Human IL-6 Immonoassay reagen and expressed in $\mathrm{pg} / \mathrm{mL}$. The event of hospitalization had been observed for 6 months. Data analysis consists of descriptive, bivariate (using comparison and chi-square test) and multivariate analysis using logistic regression.

Results: The mean serum IL-6 was 2,8 $\pm 4,09 \mathrm{pg} / \mathrm{mL}$. During observation period, there were 11 subjects (13.8\%) who hospitalized. Significant mean differences awas found between groups who experienced hospitalization (95\% IK; $\mathrm{p}<0.01)$ compared with those who didn't. Logistic regression analysis showed that serum IL-6 still had impact on hospitalization after adjusting cofounding varibables ( $95 \% \mathrm{IK} ; \mathrm{p}<0.01)$. Chi-square test showed subject with high level of serum IL-6 had a relative risk of having hospitalization was 18.8 (IK 95\%; $\mathrm{p}<0.01)$.

Conclusion: High level of serum IL-6 is a predictor for hospitalization in elderly.

Keywords: interleukin 6 , hospitalization, elderly 


\section{PENDAHULUAN}

Angka rawat inap pada pasien lanjut usia (lansia) semakin meningkat seiring pertambahan usia. Di Amerika Serikat tercatat 12,7 juta (41\%) lansia mengalami rawat inap pada tahun 2002. ${ }^{1}$ Tingginya angka rawat inap pada lansia menyebabkan semakin meningkatkan biaya kesehatan., ${ }^{1,2}$ Berbagai usaha dilakukan untuk dapat mengurangi angka kejadian rawat inap dan disabilitas pada lansia.

Salah satu faktor risiko tingginya rawat inap pada lansia adalah adanya immunosenescence. Proses penuaan sistem imun atau sering disebut dengan istilah immunosenescence merupakan terminologi yang berkaitan dengan penurunan kemampuan imunitas yang mengakibatkan individu lebih mudah terserang penyakit dan meningkatkan morbiditas dan mortalitas. ${ }^{3}$ Immunosenescence ditandai dengan adanya inflamasi sistemik kronis derajat rendah berupa peningkatan kadar penanda molekuler dan seluler dari inflamasi. Salah satu penanda dari inflamasi adalah interleukin 6 (IL-6). ${ }^{4}$

Peningkatan kadar IL-6 sering didapatkan pada lanjut usia. ${ }^{4,5}$ Peningkatan kadar IL-6 berhubungan dengan penurunan massa dan kekuatan otot bahkan terjadi pada laki-laki dan perempuan lanjut usia yang dengan status fungsional yang masih baik sebelumnya. ${ }^{6,7}$ Dalam sebuah studi longitudinal, Ferrucci dkk melaporkan bahwa peningkatan IL-6 pada saat awal memiliki risiko lebih besar untuk terjadinya disabilitas fisik dan penurunan tajam pada kekuatan otot dan kemampuan berjalan selama 3,5 tahun kedepannya pada wanita lanjut usia di komunitas. ${ }^{5}$

Penelitian ini bertujuan untuk mengetahui apakah kadar IL-6 serum merupakan faktor risiko terjadinya luaran rawat inap pada lanjut usia di komunitas.

\section{METODE}

\section{Rancangan Penelitian}

Penelitian ini merupakan studi prospektif analitik untuk mengetahui apakah kadar IL-6 serum merupakan prediktor terjadinya luaran rawat inap pada lanjut usia di Desa Pedawa Buleleng Bali.

\section{Pengambilan Sampel}

Sampel diambil dengan menggunakan stratified random sampling dari populasi lanjut usia di Desa Pedawa Buleleng Bali. Sampel penelitian adalah semua penduduk yang berusia lebih dari atau sama dengan 60 tahun yang tinggal di Desa Pedawa yang memenuhi kriteria inklusi dan tidak memenuhi kriteria eksklusi. Kriteria inklusi meliputi bersedia menjadi objek penelitian dengan menandatangani surat persetujuan kesediaan dan bersedia mengikuti petunjuk serta aturan yang telah ditetapkan oleh peneliti. Kriteria eksklusi meliputi sedang mengalami infeksi akut, mempunyai penyakit keganasan, sedang konsumsi obat anti inflamasi non steroid dan kortikosteroid, imobilitas berat atau ketergantungan berat (nilai ADL barthel < 9), memiliki riwayat rawat inap lebih dari satu kali dalam 3 bulan terakhir, ketidakmampuan untuk diwawancara karena masalah sosio-linguistik dan/atau afasia dan dengan gangguan fungsi kognitif berat. Variabel bebas pada penelitian ini adalah kadar serum IL-6 sedangkan variabel tergantung adalah luaran rawat inap. Variabel perancu adalah usia, jenis kelamin, status kerapuhan, status fungsional, komorbiditas dan status nutrisi.

\section{Prosedur Penelitian dan Pengambilan Data}

Subjek yang memenuhi kriteria inklusi serta tidak memenuhi kriteria eksklusi selama periode penelitian, dimintakan informed consent. Setelah subjek menandatangani informed consent, subjek diambil darahnya sebanyak $3 \mathrm{~mL}$ untuk pemeriksaan kadar IL-6 serum dan dilakukan anamnesis serta pemeriksaan fisik sesuai kuisoner. Dilakukan observasi selama 6 bulan dan pada akhir bulan keenam dilakukan pendataan apakah subyek mengalami rawat inap atau tidak selama periode observasi 6 bulan tersebut.

Kadar IL-6 yang diperiksa merupakan kadar IL-6. Pemeriksaan IL-6 memakai reagen Quantikine HS Human IL-6 Immonoassay (Nomer Katalog HS600B) diukur dengan metode Enzyme-linked immunosorbent assay (ELISA) dengan satuan $\mathrm{pg} / \mathrm{mL}$. Rawat inap didefinisikan sebagai proses perawatan pasien oleh tenaga kesehatan professional akibat suatu penyakit dimana pasien diinapkan selama minimal 1 hari di suatu ruangan di rumah sakit atau di puskesmas. Usia dan jenis kelamin berdasarkan data Kartu Tanda Penduduk (KTP). Status kerapuhan berdasarkan kriteria dari Fried's Frailty Phenotype. Status fungsional dinilai berdasarkan activity daily living (ADL) dari Barthel. Komorbiditas dinilai dari Charlson's-Age Comorbidity Index (CACI) dan status nutrisi berdasarkan Mini Nutritional Assesment (MNA).

\section{Analisis Data}

Pertama dilakukan uji Kolmogorov-Smirnov (KS) untuk mengetahui distribusi data. Data dianggap berdistribusi normal bila pada uji KS menunjukkan nilai $\mathrm{p}>0,05$ dan data dianggap tidak berdistribusi normal bila nilai $p<0,05$. Seluruh variabel penelitian yang berdistribusi normal akan disajikan dalam bentuk data nilai rerata [(mean \pm simpang baku (SB)], sedangkan bila tidak berdistribusi normal selanjutnya akan disajikan dalam bentuk nilai median (minimum-maksimum). Perbedaan rerata kadar IL-6 serum dengan luaran rawat inap menggunakan uji komparasi. Analisis kurva ROC digunakan untuk mencari titik potong kadar IL-6 serum. Analisis multivariat dengan regresi logistik digunakan untuk mengontrol variabel perancu. Resiko relatif kadar IL-6 serum terhadap masing-masing luaran dianilisis dengan 
menggunakan uji tabulasi silang.

\section{HASIL}

Karakteristik dasar subyek penelitian ini dapat dilihat pada Tabel 1. Pada penelitian ini didapatkan 76 orang sampel yang terdiri dari 37 orang laki-laki $(48,7 \%)$ dan 39 orang perempuan $(51,3 \%)$. Usia subjek bervariasi dari paling recil ayitu 60 tahun sampai yang paling besar 96 tahun.

Rerata kadar IL-6 serum didapatkan 2,8 $\pm 4,09 \mathrm{pg} / \mathrm{mL}$. Sebagian kecil lansia mengalami kerapuhan yaitu sebanyak 34 orang (41\%). Selama periode observasi 6 bulan didapatkan sebagian kecil subjek mengalami luaran rawat inap yaitu sebanyak 12 orang $(15,8 \%)$.

Tabel 1. Karakteristik Dasar Subjek Penelitian $(\mathrm{n}=76)$

\begin{tabular}{|c|c|}
\hline Karakteristik & $\begin{array}{c}\text { Rerata } \pm \text { SB atau } \\
\text { median (nilai } \\
\text { minimum- } \\
\text { maksimum) atau } \\
\text { frekuensi }\end{array}$ \\
\hline Usia (tahun) & $67,5(60-96)$ \\
\hline \multicolumn{2}{|l|}{ Jenis Kelamin } \\
\hline Laki & $37(48,7 \%)$ \\
\hline Perempuan & $39(51,3 \%)$ \\
\hline Kadar IL-6 serum $(\mathrm{pg} / \mathrm{mL})$ & $2,8 \pm 4,09$ \\
\hline Tinggi & $16(21,1 \%)$ \\
\hline Normal & $60(78,9 \%)$ \\
\hline \multicolumn{2}{|l|}{ Luaran Rawat Inap } \\
\hline Tidak Rawat Inap & $64(84,2 \%)$ \\
\hline Rawat Inap & $12(15,8 \%)$ \\
\hline \multicolumn{2}{|l|}{ Status Kerapuhan } \\
\hline $\mathrm{Ya}$ & $24(31,6 \%)$ \\
\hline Tidak & $52(68,4 \%)$ \\
\hline \multicolumn{2}{|l|}{ Status Fungsional } \\
\hline Mandiri & $62(81,6 \%)$ \\
\hline Tidak Mandiri & $14(18,4 \%)$ \\
\hline Skor Komorbiditas CACI & $3(2-8)$ \\
\hline \multicolumn{2}{|l|}{ Status Nutrisi } \\
\hline Malnutrisi & $4(5,3 \%)$ \\
\hline Normal & $72(94,7 \%)$ \\
\hline
\end{tabular}

CACI: Charlson's-Age Comorbidity Index

Uji komparasi menunjukkan perbedaan rerata sebesar $7,50 \mathrm{pg} / \mathrm{mL}$ yang signifikan antara kelompok yang mengalami luaran rawat inap (IK 95\%; p <0,001) dibandingkan dengan yang tidak mengalami luaran (Gambar 1 ).

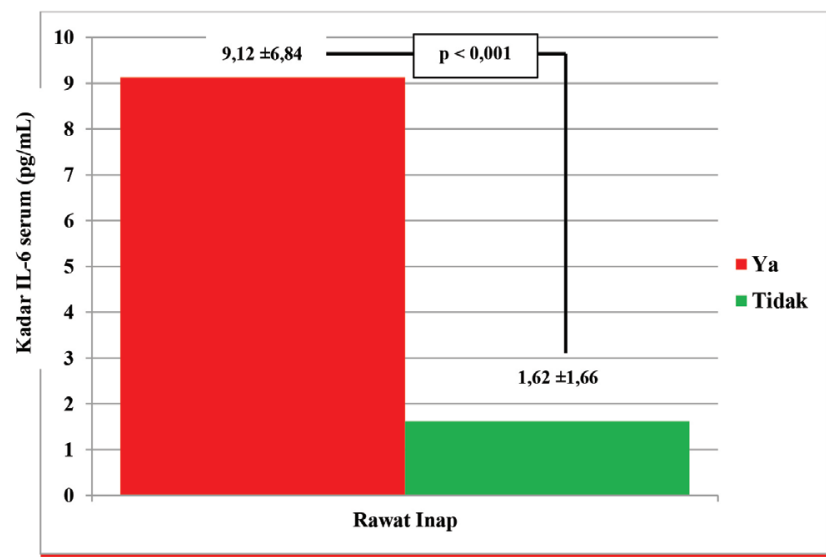

Gambar 1. Beda Rerata Kadar IL-6 Pada Luaran Rawat Inap

Penentuan nilai titik potong kadar IL-6 serum untuk luaran rawat inap menggunakan kurva ROC. Titik potong pada kurva ROC ditentukan oleh peneliti dengan memilih nilai kadar IL-6 serum berdasarkan nilai sensitivitas dan spesifisitas yang paling optimal yaitu 3,14 pg/mL (Gambar 2). Nilai kadar diatas 3,14 pg/mL tergolong kadar IL-6 serum yang tinggi sedangkan dibawah nilai tersebut tergolong kadar IL-6 serum normal.

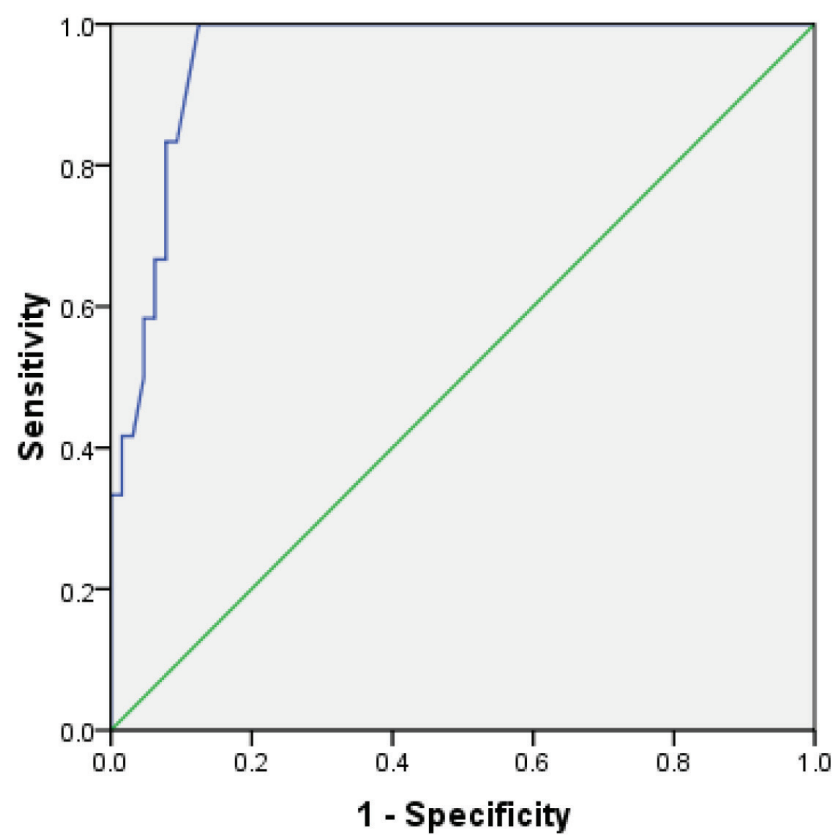

Gambar 2. Analisis Kurva ROC Kadar IL-6 serum terhadap Luaran Rawat Inap 
Uji regresi logistik menunjukkan bahwa kadar IL-6 serum yang tinggi mempunyai pengaruh terhadap luaran rawat inap $[\operatorname{Exp}(B) 35,5$; IK 95\%; p <0,01] setelah mengendalikan variabel perancu seperti usia, jenis kelamin, status kerapuhan, komorbiditas dan status nutrisi.

Tabel 2. Uji Tabulasi Silang Kadar IL-6 Serum dengan Luaran Rawat Inap

\begin{tabular}{lcc}
\hline \multirow{2}{*}{ Variabel } & \multicolumn{2}{c}{ Rawat Inap } \\
\cline { 2 - 3 } & Ya & Tidak \\
\hline Kadar IL-6 & & \\
Tinggi & $62,5 \%$ & $37,5 \%$ \\
$\quad$ Normal & $3,3 \%$ & $96,7 \%$ \\
Nilai p & & $<0,001$ \\
Resiko Relatif & \multicolumn{3}{c}{18,750} \\
IK 95\% & \multicolumn{3}{c}{$4,557-77,144$} \\
\hline
\end{tabular}

Uji tabulasi silang pada Tabel 2 menunjukkan subyek dengan kadar IL-6 serum tinggi mempunyai resiko relatif mengalami luaran rawat inap sebesar 18,8 (IK 95\%; p <0,001).

\section{DISKUSI}

IL-6 adalah sitokin proinflamasi yang sering diakitkan dengan berbagai proses patologis pada lanjut usia. Peningkatan kadar IL-6 sering didapatkan pada lanjut usia yang berhubungan dengan penurunan massa dan kekuatan otot.5 Istilah immunosenescence atau immunosenesensi digunakan untuk menggambarkan penurunan kecepatan respons sistem imun pada pasien lanjut usia dan proses inflamasi kronik diduga dapat menjadi predisposisi immunosenesensi pada usia tua. ${ }^{5,6}$

Data studi-studi sebelumnya mengenai kadar serum IL-6 sebagai prediktor luaran rawat inap belum ada. Studistudi sebelumnya lebih banyak meneliti kadar serum IL-6 sebagai prediktor kematian pada lanjut usia. ${ }^{7}$ Peningkatan IL-6 juga dikaitkan dengan penurunan massa dan kekuatan otot pada laki-laki dan perempuan lanjut usia dengan status fungsional yang masih normal sebelumnya.,8 Ferucci dkk. menemukan bahwa peningkatan IL-6 akan menjadi prediktor risiko tinggi terjadinya disabilitas fisik dan penurunan yang tajam dalam kekuatan otot dan kemampuan berjalan pada perempuan lanjut usia yang tinggal di komunitas saat periode follow-up.

Hasil penelitian ini menunjukkan bahwa kadar serum IL-6 yang tinggi merupakan faktor risiko signifikan terhadap luaran rawat inap pada lanjut usia. Hal ini dibuktikan dengan adanya perbedaan kadar serum IL-6 yang signifikan pada subyek yang mengalami luaran rawat inap dibandingkan dengan yang tidak mengalami rawat inap. Setelah mengontrol berbagai variabel yang terkait dengan luaran rawat inap pada lansia seperti usia, jenis kelamin, status kerapuhan, komorbiditas dan status nutrisi, didapatkan kadar serum IL-6 yang tinggi tetap mempengaruhi signifikan terhadap luaran rawat inap. Hal ini dapat dijelaskan bahwa kadar IL-6 yang tinggi menandakan adanya inflamasi kronik yang akan meningkatkan keadaan immunosenescence sehingga menyebabkan penurunan kemampuan berjalan dan terjadinya disabilitas fisik. ${ }^{5}$ Adanya penurunan kemampuna berjalan dan terjadinya disabiltas fisik ini dapat menyebabkan peningkatan risiko terjadinya rawat inap pada lansia.

Penelitian ini mendapatkan bahwa kadar serum IL-6 serum yang tinggi mempunyai risiko hampir sebesar 19 kali untuk mengalami rawat inap dibandingkan dengan subyek dengan kadar serum IL-6 normal. Studi-studi sebelumnya belum ada yang meneliti hal ini. Tingginya risiko rawat inap pada subyek kadar serum IL-6 tinggi menunjukkan bahwa proses inflamasi kronik memegang peranan penting dalam terjadinya morbiditas pada lansia.

Kelemahan pada penelitian ini adalah tidak menganalisis variabel waktu terjadinya luaran rawat inap sehingga tidak dapat menghitung hazard ratio kadar serum IL-6 yang tinggi.

\section{SIMPULAN}

Kadar IL-6 serum yang tinggi merupakan faktor risiko luaran rawat inap pada lanjut usia. Subyek dengan kadar IL-6 serum tinggi mempunyai risiko hampir sebesar 19 kali untuk mengalami rawat inap dibandingkan dengan subyek dengan kadar serum IL-6 normal.

\section{DAFTAR PUSTAKA}

1. Kleinpell RM, Fletcher K, Jennings BM. Reducing Functional Decline in Hospitalized Elderly. Dalam: Hughes RG, penyunting. Patient Safety and Quality: An Evidence-Based Handbook for Nurses. Edisi ke-1. Rockville: Agency for Health Care Research and Quality Publication; 2008. h.251-65.

2. Chan L, Beaver S, Maclehose RF, dkk. Disability and health care costs in the Medicare population. Arch Phys Med Rehabil. 2002;83(9):1196-1201.

3. Aspinall R, Pido-Lopez J, Imami N, dkk. Old rhesus macaques treated with interleukin-7 show increased TREC levels and respond well to influenza vaccination. Rejuvenation Res. 2007;10:5-17.

4. Leng SX, Fried LP. Inflammatory markers and Frailty. Dalam: Fulop T, Franceschi C, Hirokawa K, Pawelec G, penyunting. Handbook of Immunosenescence. Edisi ke1. Kanada: Springer Science Bussines Media BV; 2009. h.1253-1301. 
5. Ferrucci L, Penninx BW, Volpato S. Change in muscle strength explains accelerated decline of physical function in older women with high interleukin-6 serum levels. J Am Geriatr Soc. 2002;50(12):1947-1954.

6. Reuben DB, Cheh AI, Harris TB. Peripheral blood markers of inflammation predict mortality and functional decline in high-functioning community-dwelling older persons. J Am Geriatr Soc. 2002;50(4):638-644.

7. Jylha $\mathrm{M}$, Paavilainen $\mathrm{P}$, Lehtimaki $\mathrm{T}$, dkk. Interleukin-1 Receptor Antagonist, Interleukin-6, and C-Reactive Protein as Predictors of Mortality in Nonagenarians: The Vitality 90 Study. Journal of Gerontology. 2007;62(9):10161021.
8. Visser M, Pahor M, Taaffe DR. Relationship of interleukin-6 and tumor necrosis factor-alpha with muscle mass and muscle strength in elderly men and women: the Health ABC Study. J Gerontol A Biol Sci Med Sci. 2002;57(5):326-332.

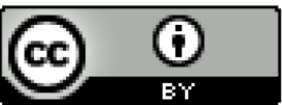

This work is licensed under a Creative Commons Attribution 4.0 International License. 